\title{
The Impact of Founder's Financial Behavior Traits and Literacy on SMEs Performance: Empirical Evidence from SMEs in Indonesia
}

\author{
Nakita Gusman ${ }^{1 *}$, Subiakto Soekarno ${ }^{2}$, Isti Raafaldini Mirzanti ${ }^{3}$ \\ 1,2,3School of Business and Management, Bandung Institute of Technology, Bandung 40132, \\ Indonesia \\ *Corresponding Author: nakita-gusman@sbm-itb.ac.id
}

\begin{abstract}
This research focuses on the SMEs development evaluation of the impact of founder's financial behavior, measured by behavioral characteristics of CEOs capacity for selfawareness, planning, and patience, also their knowledge about financial understanding which affect the ability to manage their performance of SMEs. The purpose of this research is to analyze and reduce the rate of failure of SMEs in Indonesia by pursuing the defined determinants from their behavioral traits and self-knowledge on financial understanding in decision making. This study uses a survey conducted across Indonesia, mainly on Java island, with a sample size of 482 SMEs. This research uses PLS-SEM and multivariate regression analysis as a tool for measuring the impact of founder's financial behavior variables and financial literacy variable for SMEs performance as a dependent variable. The findings show that financial literacy and three of the four variables of financial behavior traits are significant. It demonstrates that the confidence, impulsivity, financial act, and financial literacy of the founders significantly impact the soundness of SMEs. The findings also suggest that founders with strong financial knowledge and low impulsivity may make better decisions in the workplace.
\end{abstract}

Keywords: Behavioral Finance; Financial Literacy; Founder's Behavior; Multivariate Regression Analysis; SMEs Performance.

JEL Classification: D91, G53, M29

\section{INTRODUCTION}

The growth of technology and the advancement of human resources have become two key drivers for sustainable economic and social development and world leadership in all dimensions of the modern state. SMEs are widely regarded as the engines of growth, job creation, and human development worldwide, particularly in developing countries 
(Ombongi \& Long, 2018). Since years ago, small and medium-sized enterprises (SMEs) play an important role in Indonesia's socio-economic development and job creation. But we also realized that compared with other Asian countries, Indonesia still lacks on the performance of entrepreneurship. The Ease of Doing Business (EODB) 2020 index ranks Indonesia fifthlowest position in ASEAN. According to a World Bank survey of 190 countries, Indonesia ranks $73^{\text {rd }}$ with a score of 69.2. Meanwhile, Singapore is ranked second with a score of 86.2, Malaysia is ranked $12^{\text {th }}$ with a score of 81.5 , and Thailand is ranked $21^{\text {st }}$ with a score of 80.1 in other ASEAN countries. The growth of entrepreneurship has become more critical in the context of a dramatically changing global business climate. Competition in international markets has historically been the domain of large companies, whereas small and mediumsized businesses have been local or regional in scale. Removing government-imposed barriers that segregate domestic and international markets, technological advances in engineering, logistics, and telecommunications allow SMEs to participate aggressively in global business activities through either exchange or business partnerships with international companies. This changing global business environment also creates opportunities for Indonesian SMEs, as well as challenges.

When we address decision-making, bias and financial knowledge are two of the most frequently mentioned factors. It was discovered in some studies that behavior can influence someone's decision-making. It was also mentioned in research by Katarachia and Konstantinidis (2014) that, despite the research subjects learning new financial information, they were misled by psychological and financial dilemmas. In a professional setting, we sometimes assume that people frequently make rational decisions about something measurable. This assumption leads to the misconception that people have no preferences or biases when making a decision, when in fact, each person has their own biases in perceiving something. Biases distort and disrupt impartial consideration of a problem by introducing outside-the-decision factors into the decision-making process. In economics, we assume that people often make rational choices about something that can be measured. This assumption leads to the misconception that people have no preferences and biases when making a choice, while in fact, each person has its own biases in perceiving something. Kahneman (1974) stated that human decision-making is far removed from economic rationality. Even economists have their own preferences in economic view. Modern decision theory, according to Savage (1954), subjective probability decision is a behavioral phenomenon. As long as some choice is articulated as a result of the decision, there is an implied subjective probability judgment involved, which can be exposed even if the founder makes a perceptual decision of the problem and is not constantly aware of the use of empirical subjective probabilities.

Babajida and Adetiloye (2012) studied the impacts of behavioral biases on the performance of the Nigerian stock market over the last two decades, focusing on overconfidence, loss aversion, framing, anchoring, and status quo bias. In another metastudy (Fernandes et al., 2014), it is stated that an individual's financial literacy and behavioral traits influence decision making; however, the study found that financial literacy has a smaller effect on decision making than behavioral traits. From this point of view, modeling both the financial knowledge and behavior of a leader in making decisions is an important aspect since it might be one of the factors that will impact the organization's overall performance. More specifically, the analysis of the heuristic decision of the founder of small and medium-sized enterprises has become increasingly relevant as the global business environment changes and leads to entrepreneurship as an important catalyst for sustainable economic development, but in actual fact, the failure rate of small and mediumsized enterprises is $56 \%$ in 5 years; almost half of the total SMEs are likely to face failure. 
Researchers have done a lot of work showing that personality traits are important factors in economic activity (Parise and Peijnenburg, 2017). However, there is still relatively little empirical evidence in financial economics of the role that personality traits play in affecting individual and SME financial decisions. Previous studies also have shown that biased heuristics and framing effects have a negative impact on decision-making and result in loss of efficiency and profit maximization.

This research aims to contribute to the theoretical understanding of the founder as a significant source of behavioral bias, bias in decision-making and to highlight its influence on SMEs performance. When one controls for behavioral traits that have been used in previous research or when one uses a financial literacy instrument to control for omitted variables, the partial effects of financial literacy decrease significantly (Fernandes et al., 2014), highlighting that compared to financial literacy, decision making is dominated by the influence of behavioral traits. To support that claim this study will explore the concepts of financial literacy and behavioral traits to see if both are significant and influential on the Performance of SMEs. This is also based on the previous study by Agyapong and Attram (2019), financial literacy allows SMEs' owner-managers to understand and assess their own financial needs and make rational financial decisions, and the findings of their study revealed a positive influence between the firm's financial performance and financial literacy. This paper uses the data drawn from SMEs founders across Indonesia, mainly on Java Island, as a representation of Indonesia SMEs since Java Island also has the largest business capital for SMEs. The survey will explore the impact of the founder's financial literacy and financial behavior concept, namely confidence in financial information, restraint, impulsivity, and financial act, with the SME's performance indicators.

\section{HYPOTHESIS DEVELOPMENT}

\section{Financial Behavior}

According to Shefrin (2000), behavioral finance is a study of the impact of psychology on the behavior of financial practitioners and the resulting effect on markets. Baker et al. (2002) also describe the financial behavior study of how people actually behave in financial decision-making (financial settings). Several studies examine the impact of behavioral traits such as planning on financial outcomes (Ameriks et al., 2003). They discover that individuals with a high tendency to plan are more likely to develop and save financial plans than those who have not. Another trait, such as the individual's level of self-control, is that time preference is thought to capture the observable traits of managing their money. Behavioral finance theory has shown that financial actors are human beings with their own characteristics to make financial decisions. Their decision was influenced by their own behavior and psychological condition (Lutfi et al., 2016). According to Koech's (2020) research, the availability heuristic has an impact on SMEs' Performance. The availability heuristic consists of investment information, and the more information you have, the more positive the impact on SMEs' Performance. The lack of finances and the dominant role of owner-managers in making professional decisions add to the negative impact of the risk factor on SME's owner-manager attitude (Rasheed \& Siddiqui, 2019). As a result, founders wield more influence in SMEs ' decision-making. According to other research (Forbes, 2005), entrepreneurs are more vulnerable to cognitive biases than non-entrepreneurial managers. It is assumed that entrepreneurs turn to cognitive biases as a reaction to certain conditions associated with entrepreneurship, such as high time pressure, knowledge overload, and high uncertainty. According to Forbes (2005) research, there is also a positive relationship between decision comprehension and overconfidence. This result supports the 
research's goal of determining the factors that affect an SME's output through behavior variables that are considered to be a source of bias in decision making.

This study's measurement of financial behavior traits is based on a commonly developed framework obtained from several studies listed in Fernandes et al.'s metaanalysis research (2014). The first variable is confidence in information search, which is defined as "the degree to which an individual feels capable and assured with respect to decisions and behavior," and has been connected to decision-making set formation, proactive information, processing (Bearden et al., 2001), as well as measurement "How do you think banks or credit card companies would rate your credit?" (2010). The following variable is restraint and impulsivity, which was discovered by Maloney et al. in 2012. And last one, a measure of "Saving for an Emergency Fund" with yes/no answer by Lusardi and Mitchell (2007).

\section{Financial Literacy}

Financial literacy is a measure of one's understanding of key financial concepts as well as one's ability and confidence in managing personal finances through appropriate short-term decision-making and sound, long-term financial planning while keeping life events and changing economic conditions in mind (Remund, 2010). The level of financial literacy of individuals is an important indication of their ability to make financial decisions. The Organization for Economic Cooperation and Development (OECD) defines financial literacy as "not only knowledge and understanding of financial concepts and risks, but also the skills, motivation, and confidence to apply such knowledge and understanding in order to make effective decisions across a range of financial contexts, to improve the financial well-being of individuals and society." Thereby, financial literacy represents both knowledge and financial behavior. According to other research (Forbes, 2005), entrepreneurs are more vulnerable to such cognitive biases than non-entrepreneurial managers. It is assumed that entrepreneurs turn to cognitive biases as a reaction to certain conditions associated with the role of entrepreneurship, such as knowledge overload, high uncertainty, and high time pressure. According to Forbes (2005) research, there is also a positive relationship between decision comprehension and overconfidence. This result supports the research's goal of determining the factors that affect an SME's output through behavior variables that are considered to be a source of bias in decision making. Tuffour et al. (2020) also found that financial literacy among SMEs managers positively affects SME's performance. They found that financial literacy has a positive impact on both financial and non-financial SMEs performance among managers.

Financial inclusion is critical to the stabilization of the Indonesian economy. Nonetheless, according to a 2019 poll conducted by the Indonesian financial services authority, Otoritas Jasa Keuangan (OJK), Indonesia's financial inclusion rate was only $76.1 \%$. Low financial literacy appears to be the most significant obstacle to financial inclusion. According to a poll conducted by the Indonesia Fintech Association (Aftech), approximately $75 \%$ of its fintech company members cited low financial literacy among their target markets. Since then, financial literacy has been the primary focus of efforts to increase financial inclusion among Indonesian citizens. Financial literacy is also thought to be gender-biased, based on Chen and Volpe's (2002) findings that women have less knowledge about personal finance topics. However, other studies have yielded different results, notably that there is no correlation between gender and an individual's financial knowledge (Joo and Grable, 2004). In Indonesia, Buchdadi et al. (2020) discovered that financial literacy had an impact on the Performance of SMEs in the Brebes Regency. There are three main concepts of measuring financial literacy, which is as follows: (1) numeracy as it relates to the capacity to do interest rate calculations and understand interest compounding; (2) 
understanding of inflation; and (3) understanding of risk diversification (Lusardi, 2019). This study's financial literacy assessment is based on the OJK standard for assessing people's financial literacy $(\mathrm{OJK}, 2016)$. The financial literacy questionnaire has multiple choice answers but only one correct answer. If the response is correct, the respondent receives one point; if the answer is incorrect, the respondent receives zero points.

\section{Small and Medium Enterprises Performance}

Finance and capital structure decisions are one area in which the special characteristics of small and medium-sized enterprises (SMEs) and their operating environment must be considered when testing economic theories and their application in economic development. The main advantage of Indonesian micro-small and medium-sized business owners is their creativity, as the majority of products launched by Indonesian business owners are distinctive and innovative (Rahadi, 2016). The Indonesian government defines micro, small and medium-sized enterprises on the basis of their assets and revenues under Law No. 20/2008. Microenterprise is expected to have a maximum asset IDR 50.000.000 and a maximum revenue IDR 300.000.000. Meanwhile, small enterprises have maximum assets IDR 500.000.000 and maximum revenues IDR 2.500.000.000, -. Medium business is expected to have maximum assets IDR 10.000.000.000 and maximum revenues IDR 50.000.000.000. In general, micro-small and medium-sized enterprises have a positive effect on economic development in Indonesia, as they have several significant values, including the ability to absorb a large number of workers (Winarni, 2006). Companies can evaluate the signal of financial distress by looking at the state of the profits that a company generates over a certain period of time. Therefore, the company needs to know the factors that affect the financial condition of the company. The matrix of performance variables is based on previous research (Soekarno et al., 2019), which are important indicators in the assessment framework for small and medium-sized enterprises. Performance variables of small and medium-sized enterprises consist of financial activity, in which the founder plays a major role in the decision-making process. These variables include debt, leverage, profitability, and financial activity. Non-financial aspects influencing the Performance of SMEs include marketing, human resources, good governance, and operations. Each aspect has a derivative indicator whose result will be used as a score to assess an SME.

\section{Hypotheses Development}

Previous studies show that there is a correlation between financial behavior traits and financial literacy with financial decision-making. According to Forbes (2005), entrepreneurs are more vulnerable to such cognitive biases than non-entrepreneurial managers. Lusardi (2012) stated that financial education and financial literacy improve individual accountability for people's financial well-being; financial literacy influences everything from everyday decisions to long-term financial decisions, with consequences for both individuals and society. This study can observe and analyze the direct influence of the characteristics of the founder's financial behavior and financial literacy on the performance of SMEs managed by the founder by utilizing the concepts of financial behavior and financial literacy. Both the nature of financial literacy and financial behavior has a significant impact on the performance of SMEs managed by the founders. And one's decision-making. Moreover, to find out the study results, the researcher reduced this research to several hypotheses.

H1: Founder's financial behavior traits significantly influence the SMEs' performance

H2: Founder's financial literacy significantly influences the SMEs' performance 


\section{METHOD, DATA, AND ANALYSIS}

\section{Data}

The questionnaire is an important survey tool for assessing a large portion of the population. This study used an online questionnaire distributed to 482 respondents who met the specified sample criteria, including the SMEs founder who is based in Indonesia. Under Indonesian Law No.20-year (2008), small and medium-sized enterprises have assets of less than IDR 10 billion and yearly revenues of less than IDR 50 billion. This survey's questionnaire is intended to assess the impact of financial behavior traits and financial literacy on the Performance of SMEs in Indonesia. There are a variety of demographic backgrounds represented in the samples surveyed, including gender, age group, education, and others. The complete demography is shown in table 1.

Table 1. Sample Demography

\section{Demography}

Number

$\%$

Gender

Men

Female

Age

Below 24

$24-39$

$40-55$

Above 55

Education

No Degree

Elementary School

Junior High School

Senior High School

Bachelor's degree

Master's degree

PhD Degree

Education Major

Financial-related education

Other 


\section{Methodology}

The research objective of this study is to determine the impact of the founder's financial behavior traits and financial literacy on the Performance of the SMEs they eventually led. As a result, this study employed PLS-SEM and multivariate regression analysis to determine the relationship between the variables of interest. The current study used the partial least square structural equation model (PLS-SEM) methodology for data analysis. According to Avkiran and Christian (2018), PLS-SEM gives a strong outcome in the banking and finance research field. In addition to PLS-SEM, this study employs multivariate regression analysis. The multiple linear regression model is the most often used statistical tool for determining the relationship between two or more variables (Jobson, 1991). The calculations for the study are based on the model shown as equation 1.

$$
\begin{aligned}
Y(\text { SMEs soundness })= & \alpha_{0}+\beta_{1} C f d+\beta_{2} \text { Res }+\beta_{3} \text { Imp }+\beta_{4} \text { Fina }+\beta_{5} \text { Flit }+\beta_{6} G d r+\beta_{7} \text { Edu }+ \\
& \beta_{8} M j r+\beta_{9} \text { Mat }+\beta_{10} \text { Inc }+\beta_{11} \text { Ast }+\varepsilon_{i}
\end{aligned}
$$

\section{Questionnaire}

A questionnaire is the primary cross-section data collection tool in survey research. It is essentially a set of structured questions that follow a predetermined plan in order to obtain individual data on one or more specified topics. The efficiency of a questionnaire is determined by the structure it employs and the type of questions administered by the researcher (Ahmad, 2012).

\section{Demographic Questions}

This research divided educational background into seven choices: no degree, elementary school, junior high school, senior high school, bachelor's degree, master's degree, and Ph.D. degree. The educational major is divided into two choices: financialrelated education and others. Age divided based on the respondent generation: baby boomers (born 1946 to 1964), generation x (born 1965 to 1980), millennials (1981 to 1996), and generation z (1997 or after). Gender is divided into two choices: men and women. For respondent's monthly personal income, the range is from IDR below 3.000.000 IDR 3.000.000 to IDR 7.000.000, IDR 7.000.000 to IDR 12.000.000, and IDR 12.000.000 to IDR 20.000.000, and more than IDR 20.000.000. Financial Asset is ranged from IDR below 10.000.000, IDR 10.000.000 to IDR 20.000.000, IDR 20.000.000 to IDR 30.000.000, IDR 40.000.000 to IDR 50.000.000, and more than IDR 50.000.000. Last but not least is their industrial business aspects. We divided the industrial business area into three areas: services, trading or reselling, and manufacturing. The enterprise turnover divided based on the Indonesian government defines micro, small and medium-sized enterprises on the basis of their assets and revenues, which ranged from a maximum asset IDR 50.000.000 and a maximum revenue IDR 300.000.000 for micro-enterprises, a maximum asset IDR 500.000.000 and a maximum revenue IDR 2.500.000.000 for small enterprises, and maximum assets IDR 10.000.000.000 and maximum revenues IDR 50.000.000.000 for medium enterprises. The maturity of the SMEs is divided into three parts: below one year, one to three years, and above three years.

\section{SMEs Soundness Measurement}

Based on previous research (Soekarno et al., 2019), there are important indicators in the assessment framework for SMEs. The concept of soundness measurement for small and medium-sized enterprises still refers to the definition of soundness assessment for state- 
owned enterprises in Indonesia. The definition of soundness assessment for state-owned enterprises may be applied to small and medium-sized enterprises because both SOEs and SMEs have the same character in Indonesia so that they would have similar situations and conditions. There are two aspects to this SME assessment: financial aspects and nonfinancial aspects. There are various markers that differ between the two aspects. As an indication, a liquidity ratio combines the profitability ratio, activity ratio, and debt ratio. Meanwhile, non-financial variables include marketing, operations, human resources, administrative, and general issues as good governance (Subiakto et al., 2019). The component indicator explains each indicator. From the previous research, the dimensions were divided into two, external and internal factors. It is divided into inefficient and costly bureaucratic procedures and regulations in terms of external factors such as bureaucracy and finance, including lack of capital, lack of access to banks, or other formal financial institutions (Tambunan, 2011, 2009). While internal factors such as human element, which includes a lack of qualified human resources (Tambunan, 2011), innovation, which includes poor technology and little research and development, management skills, which includes management capacities, being unaware of their situation, and poor records in operation (Sriyana, 2010). SMEs Soundness Variable Operationalisation conceptually, variable, and indicators can be seen in Table 2 .

Table 2. SMEs Soundness Variable Operationalisation

\begin{tabular}{cll}
\hline \multicolumn{1}{c}{ Concept } & \multicolumn{1}{c}{ Variable } & \\
\hline & & Indicator \\
\hline \multirow{2}{*}{ SMEs Performance } & 2. Financial \\
& SMEs soundness score & 3. Marketing \\
& 4. Human resources \\
& 5. Administrative \\
& 6. General issue \\
\hline
\end{tabular}

\section{Financial Behavior Measurement}

In previous meta-analysis research (Fernandes et al., 2014), there are lists of specific knowledge and behavior traits in financial decision making; researchers used the list to objectively measure founder's behavior to see the impact of financial behavior traits on SMEs performance. The concept of financial behavior traits consists of variables that have been used in previous studies and are divided into several independent variables; confidence, restraint, impulsivity, and financial act. Financial Behavior Traits Variable Operationalisation conceptually, variable, and indicators can be seen in Table 3.

Table 3. Financial Behavior Traits Variable Operationalisation

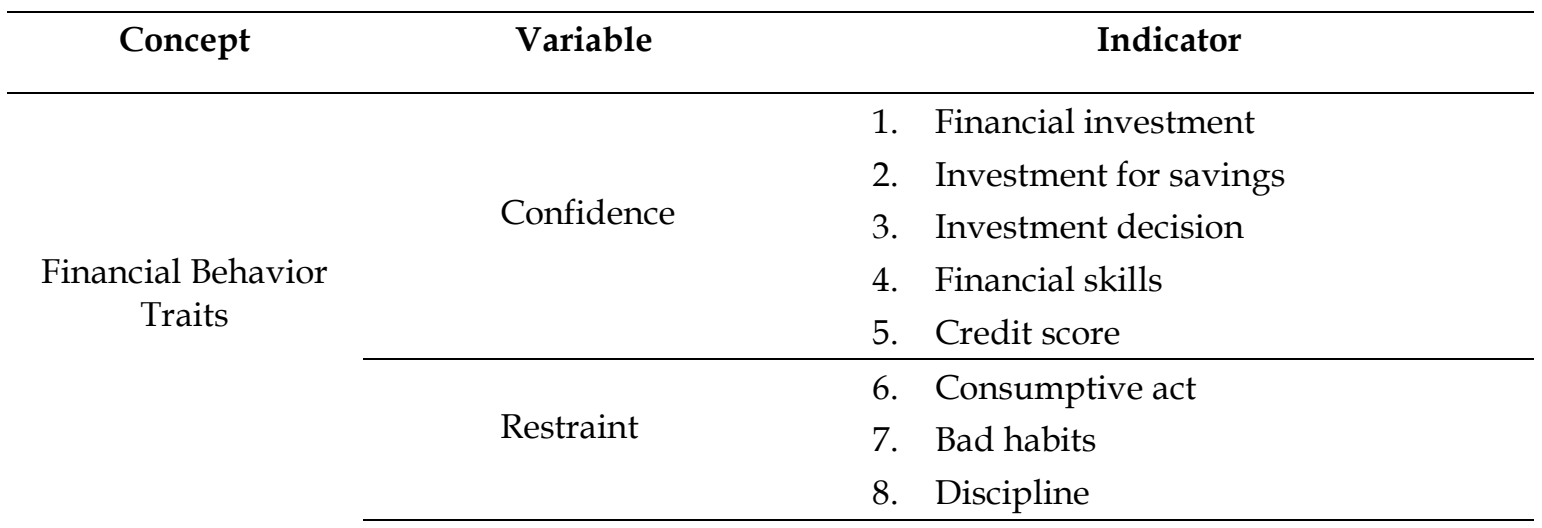




\begin{tabular}{|c|c|c|}
\hline Concept & Variable & Indicator \\
\hline & \multirow{4}{*}{ Impulsivity } & 9. Negative action \\
\hline & & 10. Work distraction \\
\hline & & 11. Resistance towards wrongdoing \\
\hline & & 12. Bad judgment \\
\hline & \multirow{5}{*}{ Financial Act } & 13. Emergency funds \\
\hline & & 14. Pension funds \\
\hline & & 15. Bond investment \\
\hline & & 16. Mutual funds investment \\
\hline & & 17. Stock investment \\
\hline
\end{tabular}

\section{Financial Literacy Questions}

Many studies have used the concept of financial literacy to assess a person's understanding of financial concepts. Financial literacy is measured by the score on financial knowledge test where each of the questions has a right answer and don't know; e.g., "If you have savings with the interest of $2 \%$ per year, inflation of $3 \%$ per year, and the money is never used, how many items can you buy in the next year? (i) More than today ; (ii) Same as today; (iii) Less than today; (iv) Don't know the answer". In this study, the questions used in measuring an individual's financial literacy were adapted from the OJK standard (OJK, 2016). The obtained score will describe an individual's level of financial literacy. Financial Literacy Variable Operationalisation conceptually, variables and indicators can be seen in table 4.

Table 4. Financial Literacy Variable Operationalisation

\begin{tabular}{cll}
\hline Concept & \multicolumn{1}{c}{ Variable } & \multicolumn{1}{c}{ Indicator } \\
\hline & & 1. Investment \\
Financial Literacy & Financial literacy score & 2. Inflation \\
& 3. Stock \\
& 4. Diversification \\
& 5. Asset knowledge \\
\hline
\end{tabular}

\section{RESULTS}

\section{Validity and Reliability Test}

The $\mathrm{R}$ table for a significance of $5 \%$ with a sample of 482 is 0.098 , indicating that the alpha coefficient value of all variables is reliable. Cronbach alpha coefficients should be between 0.3 and0.7, according to Kline (1986). If the value is less than 0.3 , the scale has insufficient internal consistency; if the value is greater than 0.7, the scale has excessive item redundancy (Schmitt, 1996). Based on the validity test results, all indicators have a probability score of 0.05 , indicating that the indicator is significant. The Sig (2-tailed) pvalue indicates whether or not your correlation was significant at a given alpha level. The $\mathrm{p}$-value is the chance of seeing a given $\mathrm{r}$-value by chance alone. If the p-value is small, which is lower than 0.05 , the correlation is significant. Validity and Reliability Test Result can be seen in Table 5. 
Table 5. Validity and Reliability Test Result

\begin{tabular}{|c|c|c|c|}
\hline Variable & Indicator & Probability & $\begin{array}{c}\text { Cronbach's } \\
\alpha\end{array}$ \\
\hline \multirow{7}{*}{$\begin{array}{l}\text { SMEs } \\
\text { Performance }\end{array}$} & 1. Financial & $0.000^{* *}$ & \multirow{7}{*}{0.445} \\
\hline & 2. Operational & $0.000^{* *}$ & \\
\hline & 3. Marketing & $0.000^{* *}$ & \\
\hline & 4. Human resources & $0.000^{* *}$ & \\
\hline & 5. Administrative & $0.000^{* *}$ & \\
\hline & 6. General issue & $0.000^{* *}$ & \\
\hline & 7. Investment & $0.000^{* *}$ & \\
\hline \multirow{3}{*}{$\begin{array}{c}\text { Financial } \\
\text { Literacy }\end{array}$} & 8. Inflation & $0.000^{* *}$ & \multirow{3}{*}{0.584} \\
\hline & 9. Stock & $0.000^{* *}$ & \\
\hline & 10. Diversification & $0.000^{* *}$ & \\
\hline \multirow{6}{*}{ Confidence } & 11. Asset knowledge & $0.000^{* *}$ & \multirow{6}{*}{0.774} \\
\hline & 12. Financial investment & $0.000^{* *}$ & \\
\hline & 13. Investment for savings & $0.000^{* *}$ & \\
\hline & 14. Investment decision & $0.000^{* *}$ & \\
\hline & 15. Financial skills & $0.000^{* *}$ & \\
\hline & 16. Credit Score & $0.000^{* *}$ & \\
\hline \multirow{3}{*}{ Restraint } & 17. Consumptive act & $0.000^{* *}$ & \multirow{3}{*}{0.805} \\
\hline & 18. Bad habits & $0.000^{* *}$ & \\
\hline & 19. Discipline & $0.000^{* *}$ & \\
\hline \multirow{4}{*}{ Impulsivity } & 20. Negative action & $0.000^{* *}$ & \multirow{4}{*}{0.689} \\
\hline & 21. Work distraction & $0.000^{* *}$ & \\
\hline & 22. Resistance towards wrongdoing & $0.000^{* *}$ & \\
\hline & 23. Bad judgment & $0.000^{* *}$ & \\
\hline \multirow{5}{*}{ Financial Act } & 24. Emergency funds & $0.000^{* *}$ & \multirow{5}{*}{0.497} \\
\hline & 25. Pension funds & $0.000^{* *}$ & \\
\hline & 26. Bond investment & $0.000^{* *}$ & \\
\hline & 27. Mutual funds investment & $0.000^{* *}$ & \\
\hline & 28. Stock investment & $0.000^{* *}$ & \\
\hline
\end{tabular}

\section{Assumption of Multiple Linear Regression}

\section{Multivariate Normality}

Many statistical procedures, such as regression, correlation, analysis of variance, and $t$-tests, are based on the assumption that the data follows a normal distribution or a Gaussian distribution; that is, the populations from which the samples are drawn are assumed to be distributed normally (Driscoll et al., 2000). This research used the Kolmogorov-Smirnov test for the normality test. The K-S test is distribution-free, which means that the critical values are independent of the distribution being tested. The null hypothesis states that the sample distribution is normal, and a p-value $<0.05$ indicates that the null hypothesis has been rejected and the distribution is not normal. This test yielded a $\mathrm{p}$-value of 0.053 , indicating that $\mathrm{H} 0$ is accepted and the data distribution is normally distributed. 


\section{Multicollinearity}

In a multiple regression model, multicollinearity indicates a high degree of linear intercorrelation between independent variables. The presence of multicollinearity causes regression analysis results to be incorrect. If there is no linear relationship between predictor variables, they are said to be orthogonal (Jensen et al., 2013). For multicollinearity, the diagnostic tools include variance inflation factor (VIF) and collinearity statistics tolerance coefficient. Multicollinearity presents when the VIF value is $>10$ and if the value of tolerance is $<0.1$. As shown in the appendix, the result of all variables tested yields VIF values no greater than ten and tolerance values greater than 0.1 , indicating that there is no correlation between all independent variables, and therefore $\mathrm{H} 0$ is accepted.

\section{Heteroscedasticity}

The score test (Cook and Weisberg, 1983) is diagnostic for heteroscedasticity that is comparable to computing the Pearson correlation between the squared residuals from an initial fit to the data and the predictor $\mathrm{z}$ (Yin and Carroll, 1990). Heteroscedasticity is defined as a systematic change in the spread of residuals across the measured value range. Heteroscedasticity is caused primarily by the presence of outliers in the data, but it can also be caused by the omission of variables from the model. This research applied Spearman's rank correlation test to detect the presence of heteroscedasticity. The null hypothesis asserts that residuals are homoscedastic with a p-value $>0.05$. The null hypothesis is accepted because the output in the appendix shows a number greater than 0.05 for each variable tested using Spearman's rank test.

\section{Impact of Founder's Financial Behavior Traits and Financial Literacy on SMEs Performance}

We used PLS-SEM and multivariate regression analysis with the objective to explain how founder behavior traits and financial literacy affect the Performance of SMEs. The final results of both PLS-SEM and multiple regression analysis are shown in Table 6.

Table 6. Results of the Structural Model Analysis

\begin{tabular}{cccc}
\hline Hypothesis & Path Coefficient & T-value & P-value \\
\hline Con -> SMES & 0.172 & 3.570 & $0.000^{* * *}$ \\
Res - > SMES & -0.001 & 0.032 & 0.974 \\
Imp -> SMES & -0.083 & 2.099 & $0.036^{* *}$ \\
FA -> SMES & 0.184 & 3.859 & $0.000^{* * *}$ \\
FL -> SMES & 0.293 & 7.421 & $0.000^{* * *}$ \\
\hline
\end{tabular}

Note: *Significant at $10 \%$ level, **Significant at $5 \%$ level, ***Significant at $1 \%$ level

The structural model analysis was performed to determine whether the model would fit the proposed study theoretical framework model's conclusions (Phan \& Zhou, 2014). According to the results shown in Table 6, four of the five variables have a significant 
relationship, while the relationship between Res to SMEs is insignificant. Con to SMEs, FA to SMEs, and FL to SMEs are positively significant, while Imp to SMEs is negatively significant. Multivariate Regression Result can be seen in Table 7.

Table 7. Multivariate Regression Result

\begin{tabular}{|c|c|c|c|}
\hline Variable & Standardized $\beta$ & T-value & P-value \\
\hline Confidence & 0.170 & 3.464 & $0.001^{* * *}$ \\
\hline Restraint & -0.027 & -.576 & 0.565 \\
\hline Impulsivity & -0.077 & -1.865 & $0.063^{*}$ \\
\hline Financial Act & 0.183 & 4.007 & $0.000^{* * *}$ \\
\hline Financial Literacy & 0.238 & 5.288 & $0.000^{* * *}$ \\
\hline Gender & -0.078 & -1.963 & $0.050^{* *}$ \\
\hline Education & 0.057 & 1.332 & 0.183 \\
\hline Major & -0.014 & -.348 & 0.728 \\
\hline SMEs Maturity & 0.051 & 1.252 & 0.211 \\
\hline SMEs Income & 0.051 & 1.152 & 0.250 \\
\hline SMEs Asset & 0.112 & 2.482 & $0.013^{* *}$ \\
\hline
\end{tabular}

Note: *Significant at 10\% level, **Significant at 5\% level, ***Significant at $1 \%$ level

Similar to the results from the PLS-SEM, the results from the multivariate regression analysis also shows that four of the five variables are significant. Furthermore, two variables from the control variables are significant.

\section{DISCUSSION}

The multivariate regression results show that only one variable of financial behavior traits has no significant influence on SMEs' performance between financial behavior traits and financial literacy. Confidence, financial act, and financial literacy are significant at the $1 \%$ level and positively correlate with SMEs' performance. A founder who has a higher score on financial literacy, confidence in their financial knowledge, and better financial knowledge to make financial decisions has a higher chance of positively impacting the enterprise they lead. As one of the financial behavior traits, impulsivity is also significant at the $10 \%$ level $(p=0.063)$, negatively correlated $(t=-1.865)$. This means that founders with 
higher levels of impulsivity are more likely to have a negative impact on the Performance of their SMEs. On the other side, restraint is the only variable that has no significant impact on the Performance of SMEs, implying that being disciplined has nothing to do with the founder's professional decision-making.

The model is also regressed with demographic variables as control variables in this study, and it is discovered that gender and SMEs asset are significant on SMEs performance. Men have a greater chance of providing positive results on SMEs performance at a $5 \%$ significance level $(p=0.050)$; this finding is contradicting the previous research, which found that women have a positive impact on business health, even though men have greater financial literacy than women (Randy, 2017). This study also discovered that men score higher in financial literacy, albeit by a small margin. On the contrary, the education and major of the founders have no significant effect on the Performance of SMEs; what matters is their financial knowledge. For SMEs, the asset positively impacts performance at a $5 \%$ significance level $(p=0.013)$. The greater the SME's asset, the greater their opportunity to improve and explore their business process. Other control variables, such as SMEs' maturity and income, have no significant effect on their performance.

\section{CONCLUSION, LIMITATIONS, AND SUGGESTIONS}

The main concern of this research is to analyze and reduce the rate of failure of SMEs in Indonesia by pursuing the defined determinants from their behavioral traits and literacy in financial fields. From this concern, we move on to the objective of this research, which is to examine the impact of the founder's behavior on decision-making and financial literacy that affects the performance of small and medium-sized enterprises. The data was processed using PLS-SEM and multivariate regression. The results show that founders' behavioral traits and financial literacy impact the Performance of the SMEs they lead. Certain behaviors, such as confidence, impulsivity, and financial act, can influence a person's decision-making in their professional scope. This is also discussed and is similar to the findings of Fernandes et al. (2014). Financial literacy is also significant in affecting the performance of SMEs. This result can occur considering that founders who are financially literate tend to understand the financial situation of their organizations and carry out better financial mitigation.

From the demographical data, despite the fact that men and women have nearly the same average financial literacy score, the results show that men have more chance of positively impacting the Performance of SMEs since the average financial literacy score on men is higher by 10 points. On the contrary, the education and major of the founders have no significant effect on the Performance of SMEs; what matters is their financial knowledge. SMEs' assets also have a positive influence on SMEs' performance. The influence could be due to the fact that assets provide capital for SMEs to avoid bankruptcy and learn more about their business.

Based on the findings, we gained insight into the determinants that are important for the business performance that leads to SMEs' success in running their business and avoiding financial distress and, ultimately, bankruptcy. The findings of this study are expected to help SMEs founders maintain favorable behavioral traits and have better financial literacy for SMEs decision-making in general activities to avoid failure and bankruptcy. The results of this study are expected to add related road map research with the fields of SMEs and Entrepreneurial Finance, particularly in policy development and implication to SMEs, to the literature. 
Despite the fact that this study successfully provides several interesting information and insights, it has some limitations. However, the samples in this study are mostly from residents of the island of Java and only slightly represent other Indonesian islands. Furthermore, the study's sample is dominated by SMEs operating in the service industry. It does not describe other types of industries such as trading and manufacturing since both types of industries are less common on the SME scale. One substantial limitation is represented by the binary distinction between manufacturing, trading, and service SMEs. As a result, the study's findings may be limited in their applicability to the manufacturing and trading industries. Based on these limitations, the authors recommend that future researchers continue to analyze the concepts used in this study and add new concepts to provide more determinant factors that influence SMEs' performance. Another suggestion is to include other industries for better application without generalization. Furthermore, future researchers should consider broadening the geographic scope of the sample to gain a better understanding of Indonesian SMEs and more robust findings.

\section{REFERENCES}

Agyapong, D., Attram, A.B. (2019). Effect of owner-managers financial literacy on the Performance of SMEs in the Cape Coast Metropolis in Ghana. J Glob Entrepr Res 9, 67. https:// doi.org/10.1186/s40497-019-0191-1

Avkiran, N. K., \& Ringle, C. M. (Eds.). (2018). Partial least squares structural equation modeling: recent advances in banking and finance. Springer International Publishing. https://doi.org/10.1007/978-3-319-71691-6

Babajide, A. A., \& Adetiloye, K. A. (2012). Investors' Behavioural Biases and the Security Market: An Empirical Study of the Nigerian Security Market. Accounting and Finance Research, 1(1). https:// doi.org/10.5430/afr.v1n1p219

Bergert, F. B., \& Nosofsky, R. M. (2011). A Response-Time Approach to Comparing Generalized Rational and Take-the-Best Models of Decision Making. Heuristics, 401426. https:// doi.org/10.1093/acprof:oso/9780199744282.003.0019

Bondt, W. F. D., \& Thaler, R. (1994). Financial Decision-Making in Markets and Firms: A behavioral Perspective. https:/ / doi.org/10.3386/w4777

Boyle, G. J., Saklofske, D. H., \& Matthews, G. (2015). Criteria for Selection and Evaluation of Scales and Measures. Measures of Personality and Social Psychological Constructs, 315. https:// doi.org/10.1016/b978-0-12-386915-9.00001-2

Brahmana, R., Siregar, W. V., \& Hsb, A. (2013). Too early to execute the strategic scenario planning: hyperbolic discounting and psychological biases of Indonesian SMEs $\begin{array}{llll}\text { managers. Business } & \text { Strategy 50 59. }\end{array}$ https:// doi.org/10.1108/17515631311325105

Buchdadi, A. D., Sholeha, A., Ahmad., G. N., \& Mukson. (2020). The Influence of Financial Literacy on SMEs Performance Through Access to Finance and Financial Risk Attitude as Mediation Variables. Academy of Accounting and Financial Studies Journal, 24(5), 1-16.

Burgstaller, J., \& Wagner, E. (2015). How do family ownership and founder management affect capital structure decisions and adjustment of SMEs? The Journal of Risk Finance, 16(1), 73-101. https://doi.org/10.1108/jrf-06-2014-0091 
Costa, D. F., Carvalho, F. de M., Moreira, B. C. de M., \& do Prado, J. W. (2017). Bibliometric analysis on the association between behavioral finance and decision making with cognitive biases such as overconfidence, anchoring effect, and confirmation bias. Journal of Scientometrics. https://doi.org/10.1007/s11192-017-2371-5

Daoud, J. I. (2017). Multicollinearity and regression analysis. Journal of Physics: Conference Series, 949, 012009. https://doi.org/10.1088/1742-6596/949/1/012009.

Davies, G. B., \& Brooks, P. (2017). Practical Challenges of Implementing behavioral finance. Oxford Scholarship https:// doi.org/10.1093/acprof:oso/9780190269999.003.0029

Online.

Driscoll, P. (2000). An introduction to everyday statistics--1. Emergency Medicine Journal, 17(3). https:/ / doi.org/10.1136/emj.17.3.205-a

Eze, S. C., Olatunji, S., Chinedu-Eze, V. C., \& Bello, A. O. (2018). Key success factors influencing SME managers' information behavior on emerging ICT (EICT) adoption decision-making in UK SMEs. The Bottom Line, 31(3/4), 250-275. https:// doi.org/10.1108/bl-02-2018-0008

Falkner, E. M., \& Hiebl, M. R. (2015). Risk management in SMEs: a systematic review of available evidence. The Journal of Risk Finance, 16(2), 122-144. https:// doi.org/10.1108/jrf-06-2014-0079

Fernandes, D., Lynch, J. G., Netemeyer, R. G. (2014). Financial Literacy, Financial Education, and Downstream Financial Behaviors. Management Science, 60(8), 1861-1883. https:// doi.org/10.1287/mnsc.2013.1849

Fiksenbaum, L., Marjanovic, Z., \& Greenglass, E. (2017). Financial threat and individuals' willingness to change financial behavior. Review of behavioral Finance, 9(2), 128-147. https:/ / doi.org/10.1108/rbf-09-2016-0056

Forbes, D. P. (2005). Are some entrepreneurs more overconfident than others? Journal of Business Venturing, 20(5), 623-640. https:// doi.org/10.1016/j.jbusvent.2004.05.001

Forbes, W., Hudson, R., Skerratt, L., \& Soufian, M. (2015). Which heuristics can aid financial-decision-making? International Review of Financial Analysis, 42, 199-210. https:// doi.org/10.1016/j.irfa.2015.07.002

Frantz, T. L., \& Jain, A. K. (2017). Relating CEO leadership behavior and organization culture in the Indian context. Leadership \& Organization Development Journal, 38(6), 746-764. https:// doi.org/10.1108/lodj-12-2015-0287

Ghobadian, A., \& Oregan, N. (2006). The Impact of Ownership on Small Firm behavior and performance. International Small Business Journal: Researching Entrepreneurship, 24(6), 555-586. https://doi.org/10.1177/0266242606069267

Kim, J. H. (2019). Multicollinearity and misleading statistical results. Korean Journal of Anesthesiology, 72(6), 558-569. https:// doi.org/10.4097/kja.19087

Koech, A. (2020). Effect of Anchoring Heuristic on Financial Performance of Small and Medium Enterprises in Nairobi, Kenya: The mediating role of Investment Decisions. Journal of Business Management and Economic Research, 4(5), 386-395. https:/ / doi.org/10.29226/tr1001.2020.223 
Lusardi, A. (2019). Financial literacy and the need for financial education: evidence and implications. Swiss J Economics Statistics 155, 1. https://doi.org/10.1186/s41937-0190027-5

Magiera, F. T. (2008). Heuristics and Biases in Retirement Savings behavior. CFA Digest, 38(1), 94-94. https://doi.org/10.2469/dig.v38.n1.43

Ombongi, P. N., \& Long, W. (2018). Factors affecting financial performance of small and medium enterprises: A case of manufacturing SMEs in Kenya. International Journal of Research in Business Studies and Management, 5(1), 37-45. https:// doi.org/10.23925/2179-3565.2019v10i3p59-65

Parise, G., \& Peijnenburg, K. (2017). Noncognitive Abilities and Financial Distress: Evidence from a Representative Household Panel. SSRN Electronic Journal. https:// doi.org/10.2139/ssrn.2924527

Perry, J. T., Chandler, G. N., Yao, X., \& Pett, T. L. (2011). Founder Characteristics and Legitimacy-Seeking behaviors. New England Journal of Entrepreneurship, 14(2), 41-51. https:// doi.org/10.1108/neje-14-02-2011-b004

Phan, K. C., \& Zhou, J. (2014). Factors influencing individual investors' behavior: An empirical study of the Vietnamese stock market. American Journal of Business and Management, 3(2), 77-94. https:// doi.org/10.11634/216796061706527

Pinnuck, M., \& Shekhar, C. (2013). The profit versus loss heuristic and firm financing decisions. Accounting, Organizations and Society, 38(6-7), 420-439. https:// doi.org/10.1016/j.aos.2013.09.003

Rahadi, R. A. (2016). Opportunities and Challenges for Micro-Small and Medium Business in Indonesia Facing ASEAN Economic Community. Jurnal Manajemen dan Kewirausahaan, 18(1), 45-53.

Randy., Soekarno, S., \& Damayanti, S. M. (2017). The Influence of Founder's Financial Literacy to Enterprises Performance. ICMEM IBS.

Rasheed, R., \& Siddiqui, S. H. (2019). Attitude for inclusive finance: influence of ownermanagers' and firms' characteristics on SMEs financial decision making. Journal of Economic and Administrative Sciences, 35(3), 158-171. https:/ / doi.org/10.1108/jeas-052018-0057

Soekarno, S., Magetsari, R. R., Mirzanti, I. R., \& Lantu, D. C. (2020). Performance assessment framework for small and medium enterprises. International Journal of Business and Globalisation, 26(1/2), 57. https:// doi.org/10.1504/ijbg.2020.109831

Sriyana, J. (2010). Strategi Pengembangan Usaha Kecil Dan Menengah (UKM): Studi Kasus Di Kabupaten Bantul. Simposium Nasional 2010: Menuju Purworejo Dinamis dan Kreatif, Yogjakarta.

Tambunan, T. (2009). Development and some constraints of SME in Indonesia. Center Industrial SME Business Competition Studies University Trisakti, Vol. 1, No. 1, pp.1-9.

Tambunan, T.T.H. (2011). Development of small and medium enterprises in a developing country: the Indonesian case. Journal of Enterprising Communities: People and Places in the Global Economy, Vol. 5, No. 1, pp.68-82. 
Tuffour, J. K., Amoako, A. A., \&amp; Amartey, E. O. (2020). Assessing the Effect of Financial Literacy Among Managers on the Performance of Small-Scale Enterprises. Global Business Review, 097215091989975. https:// doi.org/10.1177/0972150919899753

Tversky, A., \& Kahneman, D. (1982). Judgment under uncertainty: Heuristics and biases. Judgment under Uncertainty, 3-20. https:/ / doi.org/10.1017/cbo9780511809477.002

Wickham, P. A. (2003). The representativeness heuristic in judgments involving entrepreneurial success and failure. Management Decision, 41(2), 156-167. https:// doi.org/10.1108/00251740310457605

Winarni, E. S. (2006). Strategi pengembangan usaha kecil melalui peningkatan aksesibilitas kredit perbankan. Infokop, 92-98.

Wincent, J. (2005). Does size matter? Journal of Small Business and Enterprise Development, 12(3), 437-453. https://doi.org/10.1108/14626000510612330

Xiao, J. J., \& Porto, N. (2017). Financial education and financial satisfaction. International Journal of Bank Marketing, 35(5), 805-817. https:// doi.org/10.1108/ijbm-01-2016-0009

Yin, Y., \& Carroll, R. (1990). A diagnostic for heteroscedasticity based on the Spearman rank correlation. Statistics \& Probability Letters, 10(1), 69-76. https:/ / doi.org/10.1016/01677152(90)90114-m

\section{Laws}

Keputusan Menteri Hukum dan Hak Asasi Manusia No.20/2008 Tentang Usaha Mikro, Kecil, dan Menegah (2008). https://www.ojk.go.id/sustainablefinance/id/peraturan/undang-undang/Pages/Undang-Undang-RepublikIndonesia-Nomor-20-Tahun-2008-Tentang-Usaha-Mikro,-Kecil,-dan-Menengah.aspx 